\title{
ÁREAS NATURAIS TOMBADAS E A PROTEÇÃO DA PAISAGEM
}

SUELI ANGELO FURLAN UNIVERSIDADE DE SÃO PAULO, SÃO PAULO, SÃO PAULO, BRASIL

Professora assistente do Departamento de Geografia - Faculdade de Filosofia Letras e Ciências Humanas da Universidade de São Paulo (FFLCH-USP); mestre e doutora em Geografia Física pela mesma universidade. Desenvolve pesquisas socioambientais em Conservação de Florestas Tropicais coordenando os Grupos de Pesquisa Paisagem e Territorialidades na Serra do Mar e Unidades de Conservação e Desenvolvimento Local do Laboratório de Climatologia e Biogeografia/FFLCH-USP. Coordenadora do Núcleo de Estudos de Populações Humanas e Áreas Úmidas-USP. Pós-doutoranda em Florestas Culturais na Amazônia.

Email: sucaangf@usp.br

DOI

http://dx.doi.org/10.11606/issn.1980-4466.v13i26espp63-93 


\section{ÁREAS NATURAIS TOMBADAS E A PROTEÇÃO DA PAISAGEM \\ SUELI ANGELO FURLAN}

RESUMO

$\mathrm{O}$ artigo apresenta uma leitura panorâmica do passado e do presente do tombamento de áreas naturais pelo Conselho de Defesa do Patrimônio Histórico Arqueológico, Artístico e Turístico do Estado de São Paulo (Condephaat). Ressalta-se a originalidade desses tombamentos com foco na especificidade da proteção da paisagem geográfica. São apresentadas críticas e sugestões para gestão desse patrimônio e reflexões sobre a importância da ação institucional na proteção do patrimônio natural do Estado de São Paulo nestes 50 anos.

PALAVRAS-CHAVE

Paisagens. Área natural tombada. Patrimônio natural. Políticas públicas. 


\title{
LISTED NATURAL AREAS AND GEOGRAPHIC LANDSCAPE PRESERVATION \\ SUELI ANGELO FURLAN
}

\begin{abstract}
The article presents a panoramic reading of the past and the present of the listed natural areas by Conselho de Defesa do Patrimônio Histórico Arqueológico, Artístico e Turístico do Estado de São Paulo (Condephaat). The originality of these falls is emphasized with focus on the specificity of the protection of the geographical landscape. Critics and suggestions for the management of this patrimony and reflections on the importance of the institutional action in the protection of the natural patrimony of the State of São Paulo in these 50 years are presented.
\end{abstract}

\section{KEYWORDS}

Landscape. Listed natural area. Natural heritage. Public policies. 
Eu nunca guardei rebanhos,

Mas é como se os guardasse.

Minha alma é como um pastor,

Conhece o vento e o sol

E anda pela mão das Estações

A seguir e a olhar...

Quando me sento a escrever versos

Ou, passeando pelos caminhos ou pelos atalhos,

Escrevo versos num papel que está no meu pensamento...

Olhando para o meu rebanho e vendo as minhas ideias, ou

Olhando para as minhas ideias e vendo o meu rebanho

1. PESSOA, Fernando. O guardador de rebanhos. In: Poesia completa de Alberto Caeiro. [s.1.]: Nastrum, 2013. E-book. 


\section{INTRODUÇÃO}

Olhar para as ideias e homenagear a instituição onde vivi experiências que marcariam minha vida profissional é uma honra, pois apresenta-se a oportunidade de investigar o passado e o presente com certa liberdade. Narrar vivências de modo acadêmico olhando o passado a partir do presente é um desafio. Não se trata de comparar o que ocorreu no âmbito interno da instituição num percurso de tempo linear, mas de observar alguns aspectos que julgamos destacáveis da atuação institucional na sociedade. É difícil buscar esse enfoque sem uma breve apresentação de quem escreve. Tive a oportunidade de iniciar minha carreira profissional como bióloga geógrafa no Conselho de Defesa do Patrimônio Histórico Arqueológico, Artístico e Turístico do Estado de São Paulo (Condephaat), quando a partir de um processo seletivo ingressei no Serviço Técnico de Conservação e Restauro $(\mathrm{STCR})^{2}$ para compor a primeira equipe de áreas naturais ${ }^{3}$, cuja tarefa era

2. Nome dado ao serviço técnico que hoje se desdobrou em outras unidades técnicas.

3. Esta equipe era formada por um geógrafo (Wilson Morato), dois antropólogos (José Guilherme Cantor Magnani e Virgínia Valadão) e uma bióloga (a autora deste texto). Em 1986, integrou brilhantemente a pequena Equipe de Áreas Naturais o biólogo Francisco de Arruda Sampaio e o geógrafo Luís Paulo Marques Ferraz. Nos anos seguintes, a geógrafa Simone Scifoni e o ecólogo Roberto Varjabedian conduziram com alto nível técnico e nas adversidades os desafios das ANT.

Essas equipes, que se mesclaram ao longo das décadas de 1980 e 1990, assumiram a imensa tarefa de conduzir a rotina de gestão, a pesquisa e a avaliação técnica dos inúmeros pedidos de autorização para múltiplos usos nos territórios tombados. 
apoiar tecnicamente os estudos de avaliação de solicitações de tombamentos de áreas naturais e também desenvolver a rotina de atendimento a processos relativos ao patrimônio natural tombado. Depois de muitos anos, retornei ao Condephaat como Conselheira representando o Departamento de Geografia da Faculdade de Filosofia Letras e Ciências Humanas da Universidade de São Paulo (FFLCH-USP) em várias gestões. Toda iniciação profissional é como um primeiro amor, intenso e quase cego, no bom sentido. Trabalhei no Condephaat de 1982 a 1987 como técnica, mas também como aprendiz. O Conselho de Defesa do Patrimônio Histórico, Artístico, Arquitetônico e Turístico do Estado de São Paulo é uma instituição singular, pois tem um corpo técnico qualificado e engajado e um fórum de decisões representado pelo Conselho, cuja composição quase sempre reflete os embates políticos entre setores de governo, instituições de pesquisa, entidades profissionais, entre outros. No corpo técnico do Condephaat trabalham equipes com várias formações acadêmicas. O antigo Serviço Técnico de Conservação e Restauro (STCR) criou uma equipe para atuar especialmente nos estudos sobre o patrimônio natural do estado. Essa equipe de "áreas naturais" foi criada na gestão de Antonio Augusto Arantes, em 1982, e ficou responsável por dar andamento a vários estudos de tombamento de áreas naturais, tais como o da Serra do Mar e Paranapiacaba, Serra do Japi, Morro da Toca do Índio, Ilhas do Litoral Paulista, Horto Florestal de Rio Claro, entre outros. Configurou-se num período efervescente nas temáticas ambientais. Fui orientada no Condephaat por grandes mestres da preservação do patrimônio, tais como os professores Aziz Ab'Saber, Augusto Humberto Vairo Titarelli e Antônio Augusto Arantes, além de uma equipe técnica fenomenal formada por arquitetos, historiadores, antropólogos e sociólogos.

Os processos de tombamento respondem, em sua grande parte, a demandas desencadeadas por manifestações da sociedade civil, setor científico, representantes de sociedades profissionais e religiosas.

$\mathrm{Na}$ temática do patrimônio natural, o Condephaat foi um dos órgãos governamentais pioneiros a estabelecer um conjunto áreas naturais tombadas (ANT), impondo restrições à intensa degradação ambiental no Estado de São Paulo. O prof. Ab'Saber, idealizador da proposta de proteção do patrimônio paisagístico, construiu uma matriz conceitual que abriu uma frente de tombamentos de paisagens. Grandes tombamentos como 
o da Serra do Mar, o da Serra do Japi, da Serra da Cantareira, da Serra do Itapeti e de outras extensas paisagens criaram forte impacto na época e geraram uma demanda técnica na instituição. A equipe de áreas naturais era formada por três técnicos aguerridos que realizavam os estudos de campo e gabinete para melhor fundamentar essas estratégias de tombamento. Foi uma experiência ímpar e da qual resultaram posteriormente tanto o meu mestrado como o doutorado na Universidade de São Paulo.

Importante destacar que, nos anos combativos da década de 1980, essa iniciativa compunha a contracorrente da devastação. O Brasil vivia um momento político de transformação democrática. As manchetes de jornais mostravam essa efervescência numa variedade de notícias que espelhavam os sofrimentos, as conquistas e organização dos movimentos sociais em vários sentidos da conquista de direitos.

As notícias sobre a proteção do patrimônio estavam presentes na grande mídia apoiadas por uma parcela da sociedade que, no processo de democratização, se manifestava contra a degradação que se tornara intensa e alarmante na sociedade. Particularmente destacam-se os desastres ambientais como os deslizamentos das encostas em Cubatão; a poluição do ar e as ameaças de doenças que motivaram vários setores da sociedade a se organizarem em torno da luta pela proteção patrimonial e ambiental. Em uma breve pesquisa em manchetes de primeira página de jornais, encontram-se estampas de conflitos e embates da época.

Governo não permitirá invasão de terras (O Globo, 1/06/1985) Presidente garante a propriedade privada (OESP, o1/06/1985 SNI avalia as greves em São Paulo (Jornal do Brasil, 21/05/1985) Fraude no INPS pode chegar a 100 bi (Folha de São Paulo, 24/07/1985)

Serra agora é intocável, diz Montoro (OESP, 07/06/1985)

Tombamento da Serra é oficializado (Folha de São Paulo, 07/06/1985)

Saney propõe pacto nacional. E com pressa (OESP, 1985)

\section{PASSADO E PRESENTE}

Em 1985, ano em que o Governador Franco Montoro assinava o decreto de tombamento da Serra do Mar e de Paranapiacaba, essas manchetes dos 
jornais nos ajudam a contextualizar o significado de tão arrojada iniciativa do Condephaat em pleno processo de democratização do país. O tombamento de paisagens representou um grande esforço de preservação da natureza a partir de sua valorização no campo da cultura. $O$ tombamento impôs fortes restrições ao uso da terra, gerando contestações, conflitos e disputas, não apenas em relação à Serra do Mar, mas a todas as paisagens protegidas por esse instrumento. Evidentemente, o tombamento de 1.300.00o ha na zona costeira, valorizada e disputada pelos diversos setores da economia, é excepcional, mas outros conjuntos de paisagens também estão protegidos e em cada caso as restrições de uso da terra geraram controvérsias. No entanto, a decisão de proteger paisagens pelo estatuto do tombamento refletiu uma postura arrojada e desafiadora justamente por se colocar como uma contraposição à degradação do patrimônio natural do estado de São Paulo.

Ao pensar a paisagem como herança e legado que deixaremos, com suas marcas significativas, coloca-se um novo valor em disputa no território: o que deve ser valorado nessas paisagens? As paisagens representam fenômenos socioambientais complexos que nos identificam como sujeitos por seu valor estético, cultural, ambiental, histórico entre outros. Mas por que proteger paisagens? Como lutar contra a sua degradação? Como proteger a integridade do bem tombado: paisagem?

A proteção de paisagens depende de governança territorial e de abordagem técnica consistente para orientar usos e lidar com as disputas do mercado que não considera a proteção dos processos funcionais nas paisagens protegidas. Processos comandados por atributos do terreno (meio físico), seus remanescentes de cobertura (vegetações significativas) e as territorialidades humanas que imprimiram usos em conformidade com essa dinâmica. À herança fisiográfica, articula-se um significado traduzido por valores culturais associados ao conhecimento de processos naturais. Vejamos uma passagem da Resolução 40/85 (Tombamento da Serra do Mar) que define o bem tombado.

Artigo $2^{\circ} \mathrm{O}$ conjunto regional a ser tombado apresenta ao lado de seu grande valor geológico, geomorfológico, hidrológico e paisagístico, a condição de banco genético de natureza tropical, dotado de ecossistemas representativos 
em termos de fauna e flora, sendo também região capaz de funcionar como espaço serrano regulador para a manutenção das qualidades ambientais e dos recursos hídricos da região litorâneas e reverso imediato do Planalto Atlântico Paulista. A escarpa da Serra do Mar, que serviu no passado de "refúgio climático" para a floresta tropical úmida de encosta, exibe hoje os últimos remanescentes da cobertura original do Estado de São Paulo, fundamentais para a estabilidade das vertentes de altas declividades aí presentes, pouco vocacionadas para atividades agropastoris em face de sua grande vulnerabilidade ecológica, sujeita que está aos maiores impactos pluviométricos conhecidos no pais.

As ANT protegem aquilo que representa um conjunto de permanências de tempos da natureza e tempos da cultura que interessam a sociedade abrangente. As décadas de 1980 e 1990 foram a do maior número de tombamentos de paisagens ameaçadas pela voragem das obras viárias, mineração, desmatamento, loteamentos e expansão da ocupação humana urbana entre outros processos (Tabela 1).

\begin{tabular}{|c|c|c|}
\hline \multicolumn{3}{|c|}{ Tabela 1 - Tombamentos de áreas naturais - período de 1969-19874 } \\
\hline PERÍODO & SOLICITAÇÕES DE TOMBAMENTO & TOMBAMENTOS EFETIVADOS \\
\hline $1969-1975$ & 12 & 2 \\
\hline $1976-1981$ & 24 & 1 \\
\hline $1982-1992$ & 18 & 15 \\
\hline $1993-2002$ & s/d & 3 \\
\hline 2002-Atual & s/d & 2 \\
\hline
\end{tabular}

A decisão de proteger, na década de 1980, foi cientificamente fundamentada, pois não existia ainda um quadro legal amplo que permitisse a

4. Esses dados foram obtidos dos arquivos pessoais do período em que trabalhei como técnica na equipe de Áreas Naturais de 1983 a 1987 e também de pesquisa atual. Não foi possível apresentar os dados de processos não definidos até o momento para o período 1993-atual. 
sociedade reivindicar a permanência e a proteção de espaços naturais, diante da extensiva degradação ambiental. Foi um embate conflitivo diante dos fortes interesses do mercado que pressionava todos os espaços, particularmente a especulação imobiliária e a expansão urbana nos litorais paulistas. No Brasil, o Sistema Nacional das Unidades de Conservação (Lei n. 9.985 - SNUC), criadas a partir do dispositivo constitucional em $1988^{4}$, não incluiu as ANT no seu escopo de proteção, ficando a paisagem sob a tutela dos órgãos de patrimônio cultural. Assim, a proteção da paisagem passou a ser exclusivamente uma prerrogativa das instituições de proteção patrimonial.

Para a Geografia, o patrimônio natural e a paisagem como seu conceito principal são estruturantes de uma visão integradora dos processos da sociedade e natureza. Nesse sentido, a força e a ação política dos geógrafos no Conselho, na presidência do Condephaat e na área técnica foram dois dos motores da construção conceitual e do fundamento político da proteção das paisagens tombadas. Nesse cenário, é fundamental destacar a marcante passagem do dr. Aziz Ab'Saber pelo Condephaat (1975-1982), que formulou o tombamento de paisagens fundamentando-se no conceito de espaço total. Sua produção científica alicerçou a política de proteção das paisagens (AB'SABER, 1977). Detoni (2016) elaborou um resumo das diretrizes formuladas por esse autor (Quadro 1).

Os primeiros tombamentos de áreas naturais datam do início dos anos 1980 (Calçada do Lorena e os monumentos do Caminho do Mar, Maciço da Jureia, Vila Caiçara de Picinguaba e Serra do Japi são os primeiros estudos levados a tombamento).

\footnotetext{
5. Art. 225. (...) $\$ 1^{\circ}$ Para assegurar a efetividade desse direito, incumbe ao poder público: (...) III - definir, em todas as unidades da Federação, espaços territoriais e seus componentes a serem especialmente protegidos, sendo a alteração e a supressão permitidas somente através de lei, vedada qualquer utilização que comprometa a integridade dos atributos que justifiquem sua proteção.
} 


\begin{tabular}{|c|c|c|c|}
\hline \multicolumn{4}{|c|}{ Quadro 1 - Resumo das diretrizes para política de preservação de reservas naturais } \\
do Estado de São Paulo
\end{tabular}

Fonte: Adaptado de: (AB'SABER, 1997 apud DETONI, 2016).

A paisagem composta por sistemas naturais e marcas históricas do tempo social é um legado, uma herança dos processos do tempo socioambiental que transmitimos às gerações futuras. Apesar da forte marca dos fundamentos da geomorfologia, os argumentos de proteção não relegaram o tempo social que marca o Land (o uso) nas paisagens, pois esse é o atributo da exploração cultural das formas, dos solos e da cobertura vegetal. O conceito de espaço total (AB'SABER, 2002) foi utilizado para fundamentar a seleção das paisagens de destaque, como a Serra do Mar6 . No nosso entendimento, toda paisagem é processo funcional e cultural, um fato cultural como afirma Meneses (2002). Portanto, os desenhos patrimoniais dependem de uma prospecção ampla dos processos funcionais e também históricos. Essa visão parte da dinâmica dos fatos que formam os arranjos socioambientais históricos das paisagens. Para Ab’Saber, a gênese do espaço - considerado 
de um modo total - envolve uma análise da estruturação espacial realizada por ações humanas sobre os atributos remanescentes de um espaço herdado da natureza (AB'SABER, 2002, p. 30).

O princípio geral da proteção de áreas naturais pelo estatuto do tombamento foi proteger a paisagem como espaço total de remanescentes com as marcas culturais, protegendo o que não deve ser "apagado" pela supremacia dos interesses exclusivamente econômicos que, na aceleração do mercado, rapidamente eliminam as paisagens lentas, significativas e relevantes. A aceleração contemporânea elimina as marcas históricas, geomorfológicas, biogeográficas e culturais. Foi uma visão fortemente inovadora para o patrimônio e do vínculo com a cultura viva, a mais viva possível.

Além disso, havia demandas sociais, da comunidade científica e de setores da sociedade engajados no movimento ambientalista. Este último, altamente heterogêneo, apoiou muitas iniciativas do Condephaat. Não se pretende discutir as múltiplas características desse movimento, já bastante estudado (VIOLA, 1995; 1998).

Proteger espaços geográficos de grande extensão e a totalidade propriamente geográfica foi também um grande desafio técnico. De que modo desenhar a proteção da paisagem como espaço total? Na época, muitos conceitos utilizados no desenho da paisagem foram contestados, justamente por abranger diversos fenômenos sociais e frustra expectativas de mercado.

Os desenhos de proteção utilizaram critérios múltiplos procurando abranger processos de vertentes, remanescentes de vegetação, processos geológicos. Foram utilizados recursos cartográficos disponíveis à época, utilizando-se cartas topográficas do Instituto Brasileiro de Geografia e Estatística (IBGE). A escala de desenho mais utilizada foi 1:50.00o e os perímetros por cotas altimétricas, polígonos definidos por coordenadas geográficas, manchas de ecossistemas. Vejamos alguns exemplos. 
FIGURA 1

Setor tombado no polígono do tombamento da Serra do Mar - a

linha contínua define o perímetro tombado por uma mancha de ecossistema manguezal e estuário do rio Itapanhaú. A linha pontilhada representa o limite do PE Serra do Mar. Fonte: CONSELHO DE DEFESA DO PATRIMÔNIO HISTÓRICO

ARQUEOLÓGICO ARTÍSTICO E

TURÍSTICO DO

ESTADO DE SÃO PAULO. Disponível em: <http:// condephaat.sp.gov. $\mathrm{br} / \mathrm{wp}$-content/ uploads/2018/03/22

-Sao-Sebastiao.jpg>. Acesso em 22 mar. 2018.

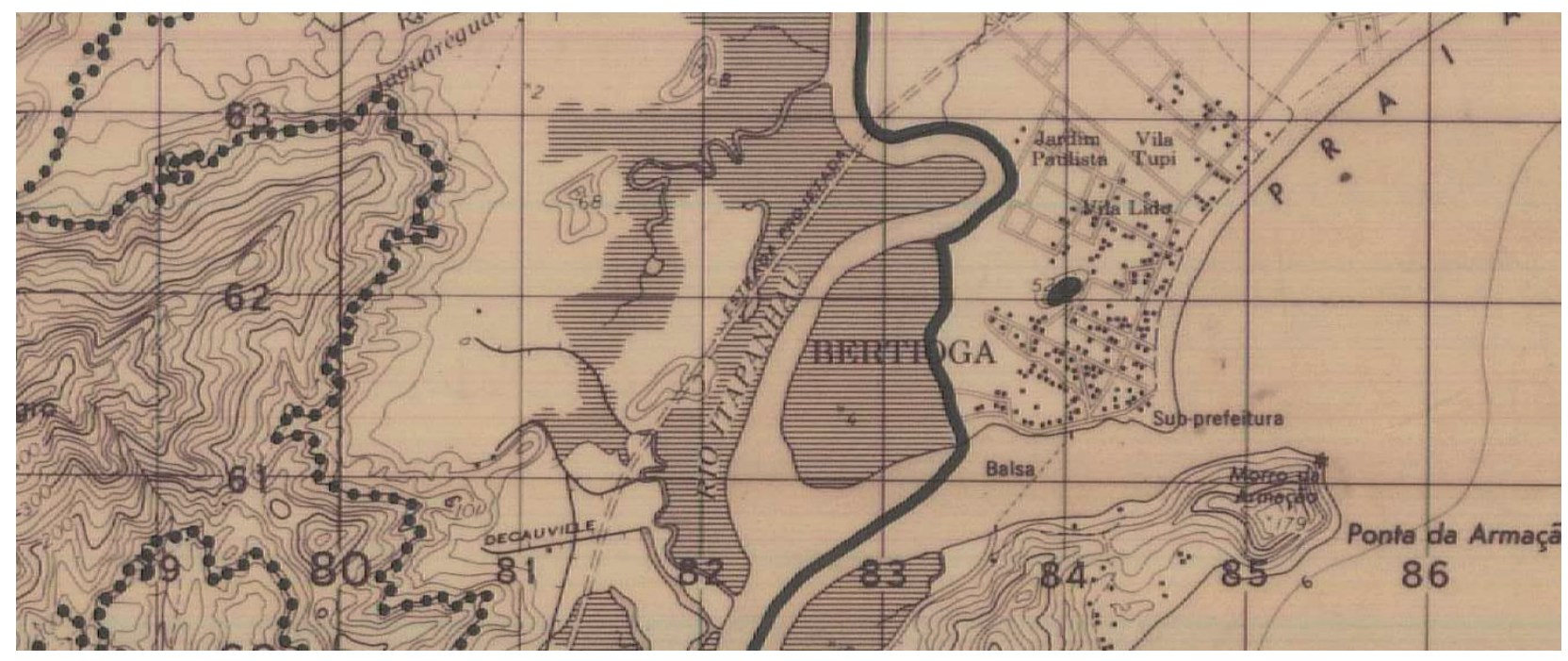

FIGURA 2

Perímetro definido por cota. Neste caso, a

linha contínua de tombamento define a cota

de 40 metros como

limite do tombamento

(mais $\mathbf{3 0 0}$ metros de área envoltória).

A linha pontilhada

representa o limite do PE Serra do Mar. Fonte: CONSELHO

DE DEFESA DO

PATRIMÔNIO

HISTÓRICO

ARQUEOLÓGICO

ARTÍSTICO E

TURÍSTICO DO

ESTADO DE SÃO

PAULO. Disponível em:

<http://condephaat.

sp.gov.br/wp-content/

uploads/2018/03/20

-Bertioga.jpg>. Acesso em: 22 mar. 2018

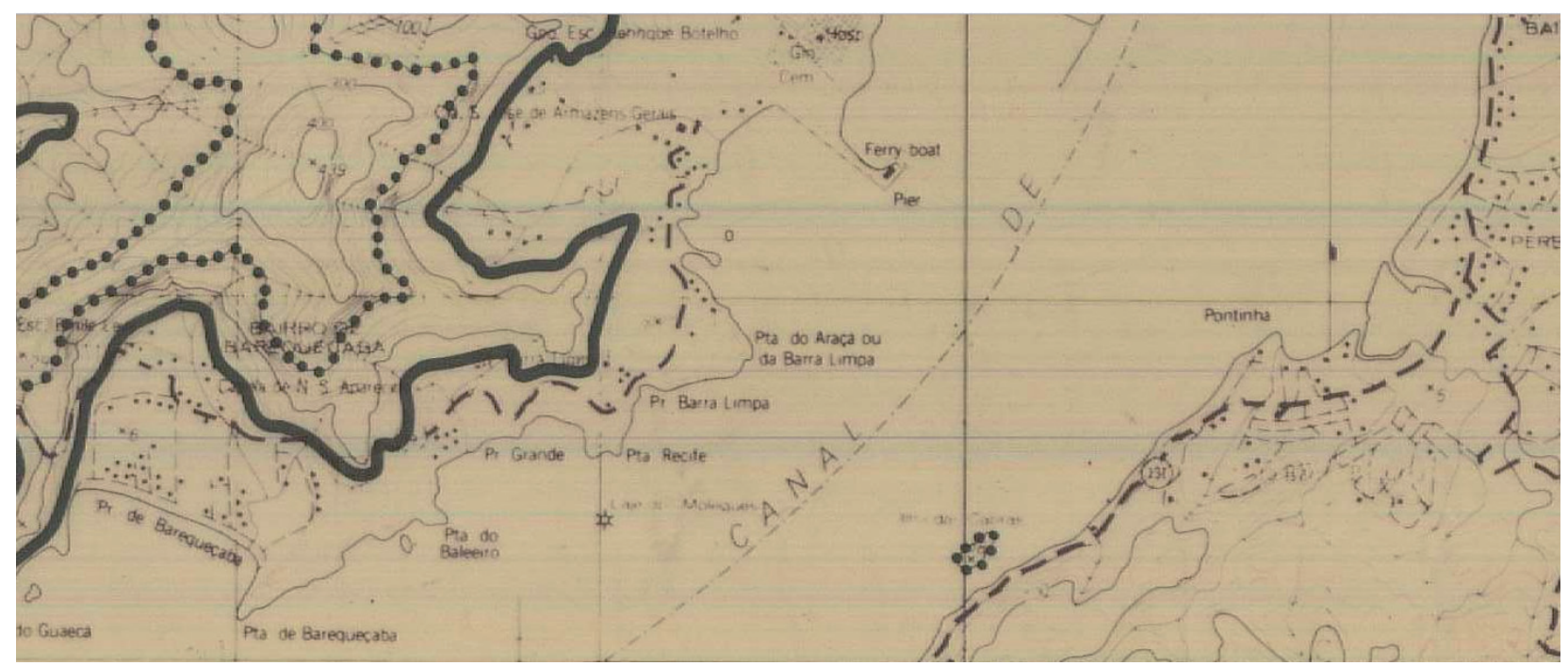




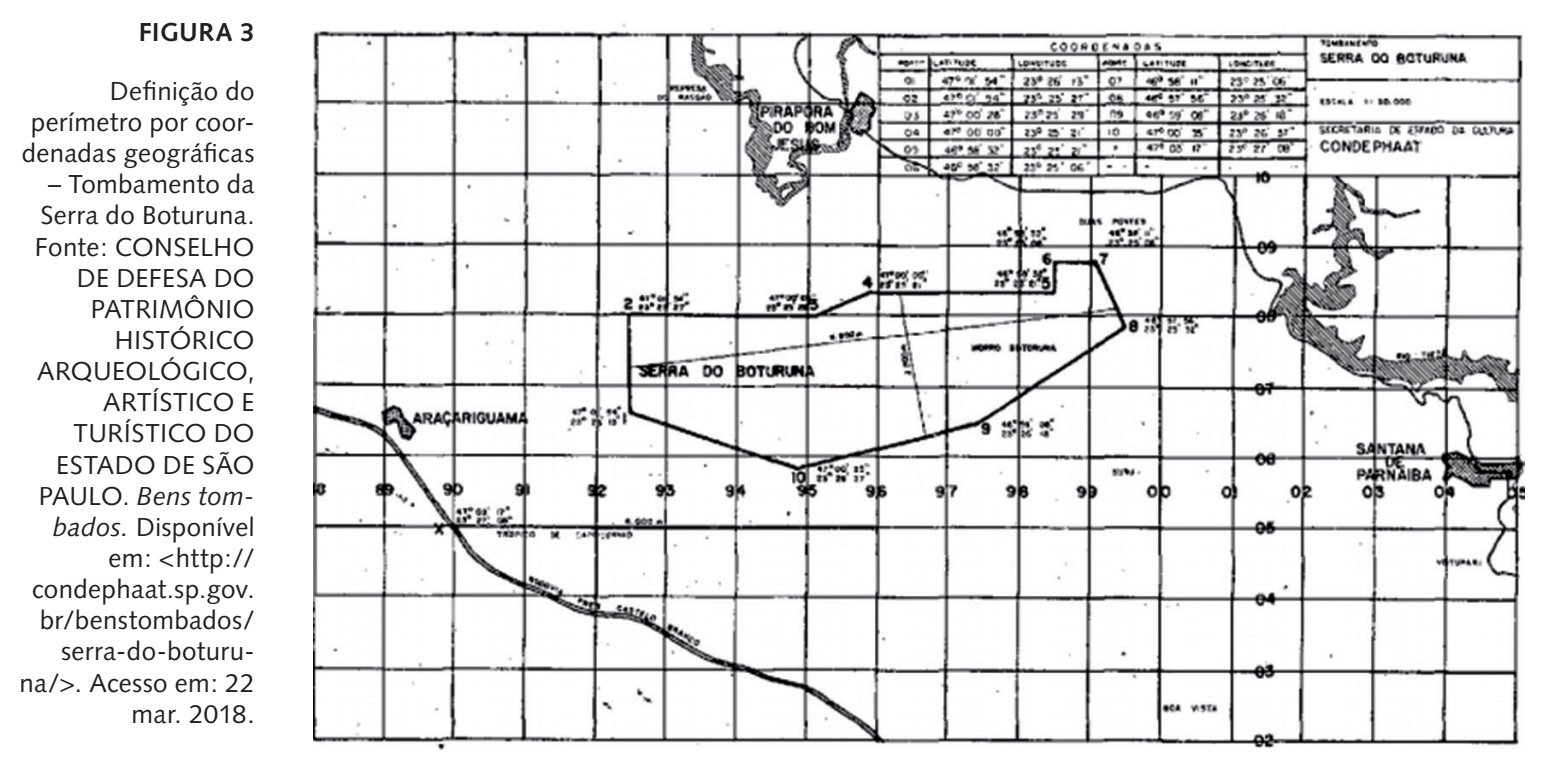

Abordaremos esses métodos de desenho para proteger os bens tombados em sua integralidade nos próximos itens. Segundo informações da Base de dados do Condephaat, o Estado de São Paulo tem 23 ANT. São elas (consideramos apenas paisagens):

\begin{tabular}{|c|c|c|c|}
\hline \multicolumn{4}{|c|}{ Quadro 2 - Áreas naturais tombadas no Estado de São Paulo. } \\
\hline ÁREA NATURAL TOMBADA & MUNICÍPIO(S) & $\begin{array}{c}\text { DATA } \\
\text { ABERTURA } \\
\text { DO PROCESSO }\end{array}$ & $\begin{array}{c}\text { DATA } \\
\text { TOMBAMENTO }\end{array}$ \\
\hline Sitio dos Jequitibás & Campinas & 1969 & 1970 \\
\hline Chácara Tangará & São Paulo & 1989 & 1994 \\
\hline Cratera de Colônia & São Paulo & 1995 & 2003 \\
\hline Ilhas, Ilhotas e Lajes & $\begin{array}{c}\text { Ubatuba, Caraguatatuba, Itanhaém, } \\
\text { Santos, São Sebastião. }\end{array}$ & 1989 & 1994 \\
\hline Maciço de Jureia e Rio Verde & Iguape & 1973 & 1979 \\
\hline Morro do Botelho & Guarujá & 1983 & 1984 \\
\hline Morro do Juquery e Pico Olho & Mairiporã & 1992 & 2004 \\
\hline D'água & Guarujá & 1978 & 1985 \\
\hline $\begin{array}{c}\text { Morros do Monduba, do Pinto e do } \\
\text { Icanhema }\end{array}$ & Salesópolis & 1974 & 1990 \\
\hline Nascente do rio Tietê & Porto Feliz & 1969 & 1972 \\
\hline Parque das Monções & São Paulo, Osasco & 1978 & 1983 \\
\hline Parque Estadual do Jaraguá & Itu & 1969 & 1974 \\
\hline Pedreira de Varvitos & Paulo & 1978 & 1983 \\
\hline Reserva Estadual da Cantareira e \\
Horto Florestal & Caieiras, Guarulhos, Mairiporã, São & & \\
\hline
\end{tabular}

(Continua) 


\begin{tabular}{|c|c|c|c|}
\hline \multicolumn{4}{|c|}{ Quadro 2 - Áreas naturais tombadas no Estado de São Paulo (Continuação) } \\
\hline ÁREA NATURAL TOMBADA & MUNICÍPIO(S) & $\begin{array}{c}\text { DATA } \\
\text { ABERTURA } \\
\text { DO PROCESSO }\end{array}$ & $\begin{array}{c}\text { DATA } \\
\text { TOMBAMENTO }\end{array}$ \\
\hline $\begin{array}{c}\text { Reserva Florestal da Fundação José } \\
\text { Pedro de Oliveira Costa Antiga } \\
\text { Fazenda Genebra }\end{array}$ & Campinas & 1982 & 1983 \\
\hline Reserva Florestal do Morro Grande & Cotia & 1978 & 1981 \\
\hline Rocha Moutonné & Salto & 1975 & 1992 \\
\hline Ruínas do Engenho dos Erasmos & Santos & 1973 & 1974 \\
\hline Serra de Atibaia e Itapetininga & Atibaia, Bom Jesus dos Perdões & 1982 & 1983 \\
\hline Serra do Boturuna & São Roque & 1982 & 1983 \\
\hline $\begin{array}{l}\text { Serra do Guararu e Vila da Prainha } \\
\text { Branca }\end{array}$ & Guarujá & 1978 & 1985 \\
\hline $\begin{array}{l}\text { Serra do Japi, Guaximduba, } \\
\text { Jaguacoara }\end{array}$ & Jundiaí & 1979 & 1983 \\
\hline Serra do Mar e Paranapiacaba & $\begin{array}{c}\text { Apiaí, Barra do Turvo, Biritiba- } \\
\text { Mirim, Cananeia, Capão Bonito, } \\
\text { Caraguatatuba, Cubatão, Cunha, } \\
\text { Eldorado, Embu-Guaçu, Guapiara, } \\
\text { Ibiúna, Iguape, Ilhabela, Iporanga, } \\
\text { Itanhaém, Itariri, Jacupiranga, Juquiá, } \\
\text { Juquitiba, Mauá, Miracatu, Mococa, } \\
\text { Mogi das Cruzes, Mongaguá, } \\
\text { Natividade da Serra, Paraíbuna, } \\
\text { Pedro de Toledo, Peruibe, Piedade, } \\
\text { Pilar do Sul, Praia Grande, Rio } \\
\text { Grande da Serra, Salesópolis, Santo } \\
\text { André, Santos, São Bernardo do } \\
\text { Campo, São Luiz do Paraitinga, São } \\
\text { Miguel do Arcanjo, São Paulo, São } \\
\text { Sebastião, São Vicente, Sete Barras, } \\
\text { Suzano, Tapiraí, Ubatuba. }\end{array}$ & 1979 & 1985 \\
\hline Vale do Quilombo & Santos & 1987 & 1988 \\
\hline
\end{tabular}

\section{SERRA DO MAR E PARANAPIACABA: A MURALHA FLORESTADA}

Foi o geógrafo Augusto Humberto V. Titarelli quem protagonizou junto com o arquiteto José Pedro de Oliveira Costa, na gestão do advogado Modesto Carvalhosa, a finalização do processo de tombamento da Serra do Mar com apoio institucional de vários órgãos do governo da época. A declaração do Tombamento da Serra do Mar foi o final de um processo técnico-científico, mas mais do que isto, um fato político que marcava o início de uma época de institucionalização das políticas de proteção de paisagens. Ao apresentar a proposta de tombamento da Serra do Mar em 1985, e defender sua aprovação junto ao governo do estado de São Paulo o Condephaat assumia a responsabilidade pública da concepção de preservação do patrimônio

7. O processo de tombamento da Serra do Mar e de Paranapiacaba foi aberto em 1982, mas concluído somente em 1985, no Governo Franco Montoro. 
natural do estado de São Paulo. A atitude do Condephaat foi seguida pelos demais estados do Paraná, Espírito Santo, Santa Catarina e Rio de Janeiro formando o primeiro grande projeto de regulação do uso e contenção do desmatamento, frente a expansão urbana e demais usos industriais que se implantavam nos últimos remanescentes dessas florestas ainda contínuas e seus ecossistemas associados, tais como restingas e manguezais. A equipe de áreas naturais do Condephaat vivia intensamente a construção dessa nova política de conservação do patrimônio no Estado de São Paulo, em particular um momento de ressignificação conceitual sobre bens a serem protegidos pelo estatuto do tombamento. Incorporava-se efetivamente a ideia de que a natureza guarda em suas formas, hidrografias, ecossistemas e arranjo socioespacial a memória socioambiental de uma região. $\mathrm{O}$ tombamento da Serra do Mar inovou iniciando, ao mesmo tempo, uma ótica de planejamento do uso da terra mantendo o direito de propriedade, portanto sem desapropriar, mas intervindo no uso do território. Podemos dizer que o design with nature (MCHARG,1969), chegava aos instrumentos

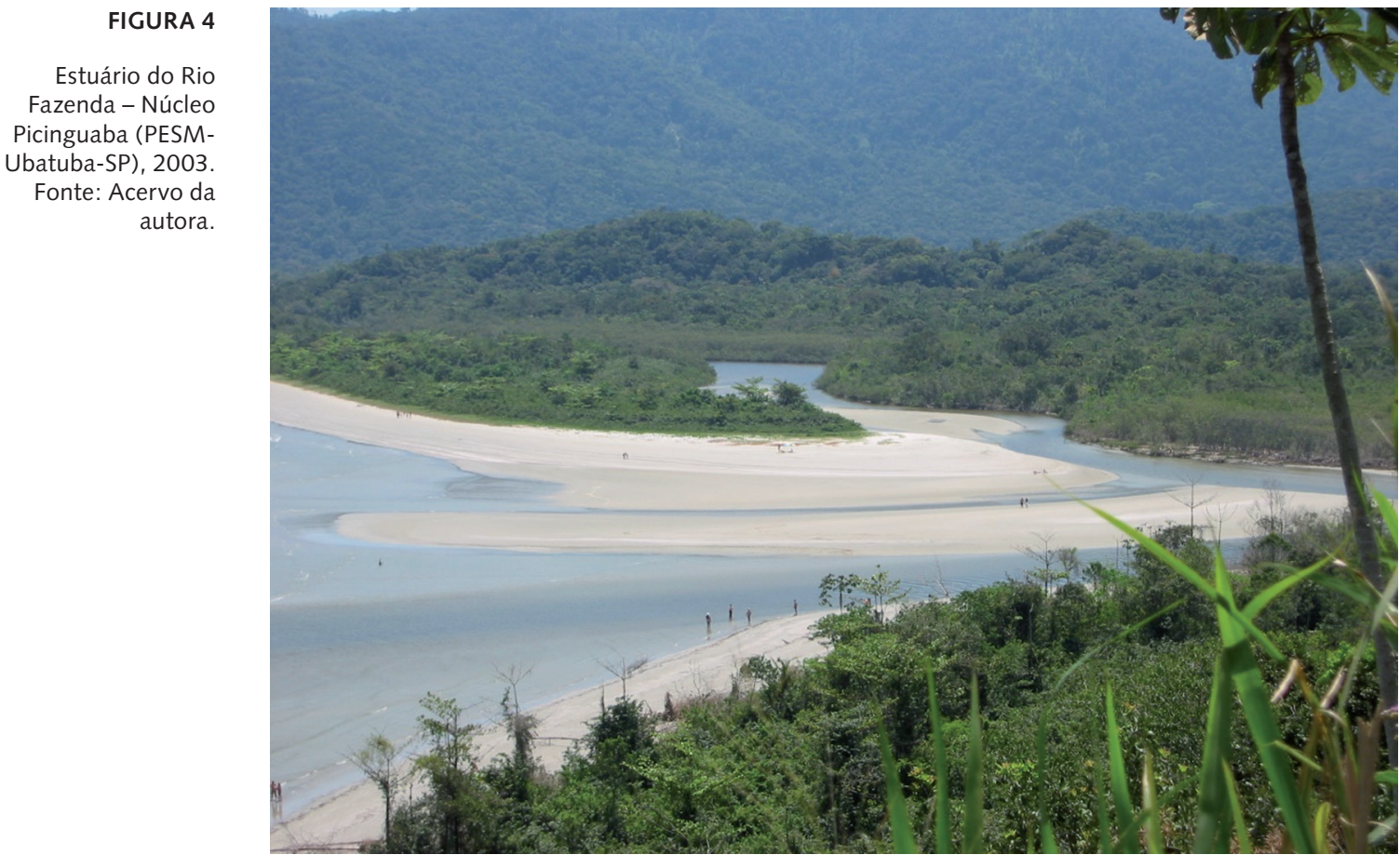


patrimoniais. Desenhar a proteção da paisagem é desenhar processos funcionais como veremos adiante. Muitos questionamentos dos desenhos que surgiram após a decisão de tombar se referem a como cartografar os valores descritos nos tombamentos.

O tombamento da Serra do Mar e de Paranapiacaba foi exemplo emblemático desta singularidade ambiental, pois é formada por relevos dissecados recobertos por um mosaico de remanescentes de florestas tropicais pluviais ${ }^{8}$ que, ao longo do tempo, foram afetadas pelo intenso processo de capitalização das terras nas cotas baixas dos litorais no eixo Paraná-São Paulo-Rio de Janeiro, onde os usos industriais, portuários, a expansão urbana, os loteamentos, a mineração e a silvicultura industrial foram varrendo as florestas e seus ecossistemas associados.

Criar novos conceitos de uso do território e, de certo modo, atuar na contracorrente da especulação imobiliária não foi simples nem fácil e, nesses 50 anos, o Condephaat ainda enfrenta inúmeras pressões econômicas sobre essas ANT. Lamentavelmente, o desenvolvimento da gestão do patrimônio natural não se desenvolveu no tamanho de sua importância.

Para os primeiros passos do planejamento da paisagem tombada da Serra do Mar, em 1986-1987, o Governo do Estado instituiu um grupo de trabalho coordenado pela Empresa Paulista de Planejamento Metropolitano S/A (Emplasa) e encarregado de desenvolver o Plano Sistematizador do Tombamento das Serras do Mar e Parnapiacaba. O objetivo desse Plano foi regulamentar o tombamento da Serra do Mar. A necessidade de conservação desse extenso e importante complexo serrano havia motivado várias intervenções do poder público que criou parques, estações ecológicas e outras áreas de proteção ambiental ao longo dessa faixa do território paulista. $\mathrm{O}$ plano visava indicar diretrizes de planejamento e indicar estudos específicos para maior detalhamento de normas e critérios para o uso da terra.

O plano foi finalizado e publicado no Diário Oficial em 1989. Infelizmente, o Plano desenvolveu somente sua primeira etapa, sistematizando a cartografia básica da região, e definindo as diretrizes gerais e normas preliminares para o controle, uso e ocupação da terra. Atributos da paisagem tombada, segundo o Plano Sistematizador, valeriam como 
referência para analisar solicitações ao Condephaat. Na Tabela 2, são listadas as áreas protegidas que foram abrangidas pelo tombamento da Serra do Mar com sua classificação atual.

\begin{tabular}{|c|c|}
\hline \multicolumn{2}{|c|}{ Tabela 2 - Serra do Mar e Paranapiacaba - áreas protegidas } \\
\hline $\begin{array}{l}\text { ANT - SERRA DO MAR E PARANAPIACABA } \\
\text { (RESOLUÇÃO 40/1985 - CONDEPHAAT) }\end{array}$ & CLASSIFICAÇÃO ATUAL \\
\hline \multicolumn{2}{|l|}{ PE Turístico do Alto Ribeira - PETAR } \\
\hline \multicolumn{2}{|l|}{ PE Carlos Botelho } \\
\hline PE Jacupiranga & $\begin{array}{c}\text { PE Caverna do Diabo } \\
\text { PE do Rio Turvo } \\
\text { PE do Lagamar Cananeia } \\
\text { APA dos Quilombos do Médio Ribeira } \\
\text { APA de Cajati } \\
\text { APA do Rio Vermelho e Rio Pardinho } \\
\text { APA Planalto do Turvo } \\
\text { RDS de Lavras } \\
\text { RDS dos Quilombos de Barra do Turvo } \\
\text { RDS dos Pinheirinhos } \\
\text { RDS Barreiro/Anhemas }\end{array}$ \\
\hline \multicolumn{2}{|l|}{ PE Ilha do Cardoso } \\
\hline \multicolumn{2}{|l|}{ PE Serra do Mar } \\
\hline \multicolumn{2}{|l|}{ PE Ilhabela } \\
\hline \multicolumn{2}{|l|}{ PE Ilha Anchieta } \\
\hline \multicolumn{2}{|l|}{$\begin{array}{l}\text { Reserva Biológica do Alto da Serra de } \\
\text { Paranapiacaba }\end{array}$} \\
\hline Reserva Estadual do $2^{\circ}$ Perímetro de São Roque & PE Jurupará \\
\hline Reserva Estadual do $18^{\circ}$ Perímetro de Iguape & EE Chauás \\
\hline Reserva Estadual Xituê & EE Xituê \\
\hline Reserva Estadual Itatins & EE Jureia \\
\hline Estação Ecológica da Jureia & EE Jureia \\
\hline \multicolumn{2}{|l|}{ APA Cananeia, Iguape, Peruíbe } \\
\hline APA Serra do Mar & \\
\hline
\end{tabular}

O documento que foi publicado no Diário Oficial, deveria, desde então, ser o ponto de partida para o aperfeiçoamento da gestão da área tombada da Serra do Mar. O plano foi elaborado por uma equipe multidisciplinar com a participação de vários órgãos do sistema de governo da época. Essas diretrizes valem para as áreas tombadas não declaradas como Unidades de Conservação (UC), pois elas têm seus planos de manejo próprios. Importante destacar que os planos de manejo dessas UC consideram a ANT como sua zona de amortecimento, ou seja, zona que deve atuar como coadjuvante da proteção ambiental. ${ }^{9}$

9. Diretrizes, normas e recomendações preliminares. Aprovadas pelo Egrégio Colegiado em $22 \mathrm{de}$ janeiro de 1987.Publicado no DOE, Seção I, São Paulo, em 14 de janeiro de 1989, p. 13. 
O Plano foi elaborado pela Equipe de Áreas Naturais do Condephaat ${ }^{10}$ usando dados e informações reunidos durante a elaboração da Primeira Fase do Plano Sistematizador do Tombamento da Serra do Mar, (...) realizada em conjunto pelo Condephaat, Secretaria de Estado do Meio Ambiente e Emplasa, com a colaboração técnica e material de instituições da época como a Superintendência do Desenvolvimento do Litoral Paulista (Sudelpa), Secretaria de Estado da Agricultura e Abastecimento, Companhia Ambiental do (Cetesb), Companhia de Saneamento Básico do Estado de São Paulo (Sabesp) e Instituto Agronômico de Campinas.

Essas diretrizes estão vigentes e precisam ser atualizadas pelo Condephaat. Houve momentos em que seu uso foi desautorizado pelo próprio Conselho do órgão. Seria fundamental reavaliar e avançar na gestão dos tombamentos de ANT, considerando-se novos conceitos e tecnologias. Continuam válidas as diretrizes gerais para indicar bens da natureza que podem ser protegidos por tombamento. Detoni (2016), em seu estudo sobre as paisagens protegidas pelo Condephaat, retoma essas tipologias que podem ser:

1. Formas de vegetação nativa remanescentes, em especial áreas ameaçadas de extinção.

2. Formas de vegetação secundária que se destacam pelo valor científico e pela escassez.

3. Áreas que se destacam pela existência de monumentos ecológicos, geomorfológicos, etc.

4. Áreas cuja paisagem mantém o equilíbrio do sistema ambiental e mananciais de água.

5. Áreas consideradas hábitats de espécies raras de animais.

6. Paisagens produto da ação antrópica com manejo que leva em conta a preservação.

7. Toda paisagem alterada ou não pela ação do homem que se caracterize pela sua expressividade, raridade e beleza excepcional e pelo que ela apresente como interesse social.

10. Participaram deste estudo Francisco Arruda Sampaio (coordenador da equipe), Sueli Ângelo Furlan (técnica); Luís Paulo Marques Ferraz (técnico); Roberto Varjabedian (estagiário voluntário). 


\section{COMO PROTEGER O PATRIMÔNIO: PAISAGEM?}

A proteção da paisagem deve se dar num processo de conservação educadora ${ }^{11}$. Conservação que valorize a importância da herança socioambiental já reconhecida em estudos científicos bioclimáticos do quaternário sobre as paisagens complexas. Herança que, ao mesmo tempo, dissemina os saberes locais incluindo o valor socioambiental. As paisagens protegidas pelo Condephaat como ANT são portadoras da história ambiental e cultural. Do ponto de vista do patrimônio natural, é urgente o inventário dos redutos representativos da geomorfogênese do Estado de São Paulo que resultaram em conjuntos paisagísticos ainda não protegidos no Estado.

Segundo Scifoni (2006, p. 7) as paisagens tombadas pelo Condephaat podem se inserir nos três critérios que a Organização das Nações Unidas para a Educação, a Ciência e a Cultura (Unesco) (1977) definiu para nortear o reconhecimento do valor universal estético, ecológico e científico das paisagens:

- Valor estético - paisagens notáveis e de extraordinária beleza natural ou em condição de exceção, como bem apontou Ab'Saber (1984).

- Valor ecológico - corresponde aos sítios - hábitat de espécies em risco de extinção ou como detentoras de processos ecológicos e biológicos importantes, como é o caso dos remanescentes das Matas Atlânticas nebulares, campos de altitude, redutos de araucárias na Serra da Mantiqueira.

- Valor científico - manifesta-se em áreas que contenham formações ou fenômenos naturais relevantes para o conhecimento científico da história natural do planeta, a exemplo da formação da Serra da Mantiqueira e a herança biogeográfica representada pelos redutos das oscilações climáticas do quaternário.

O inventário de paisagens do estado de São Paulo ainda não foi feito. Segundo Scifoni (2006, p. 8), a "condição essencial para o seu reconhecimento é o estado de integridade dos bens". É aqui que a interface entre os processos funcionais ecossistêmicos, biogeofísicos e educadores devem

11. Entende-se como um processo dialógico de produção e difusão de saberes locais e acadêmicos num processo de construção participativa. 
ser bem compreendidos para uma efetiva proteção. Ou seja, se o valor estético é representado pela morfologia do relevo é fundamental proteger a morfologia de práticas que degradam as formas como a mineração que elimina a forma da paisagem. Se o atributo estético é uma queda d'água, é fundamental preservar a bacia hidrográfica. Ainda segundo a autora, "pelo critério ecológico, a área deve incluir condições de integridade ecossistema", por exemplo, os corredores de vegetação para fluxo da biodiversidade (SCIFONI, 2006, p. 66). Pelo critério científico, integridade podem ser, por exemplo, as turfeiras, os sítios arqueológicos, morros testemunhos etc.

Proteger a paisagem exige recolocar a discussão do patrimônio natural diante do que este representa no âmbito das três dimensões da cultura, propostas pela Unesco. Qual é seu significado simbólico? Considerando estudos da paisagem em diferentes abordagens (culturalistas e ecológicas), teremos coragem de preservar um bem cultural de natureza complexa como setores da Serra da Mantiqueira? Mais do que a leitura de um espaço complexo, o desafio das paisagens revela tempos, usos, ocupações, querências, objetos e ações. Paisagens ameaçadas pelas possibilidades da expansão urbana, da mineração, do turismo, da expansão da silvicultura, da fragilização da legislação florestal, mineração entre outros.

A incorporação dos processos funcionais no pensar e promover a proteção das paisagens pode efetivamente contribuir para a obtenção de desenho dos territórios buscando a paisagem integradora, mais justa e diversificada. É preciso retomar os preceitos de proteção que auxiliem na percepção do modo nem sempre justo, nem sempre mais adequado, nem sempre sustentável, de como fazemos a inserção institucional do patrimônio no caminho da proteção de um bem natural de valor cultural. Devemos ter coragem e responsabilidade para rediscutir esse tema no âmbito do Condephaat de modo a garantir que um legado de milhões de anos de processos naturais e sociais não seja dizimado por processos sociais econômicos que impeçam o acesso das gerações futuras a esse legado de informações naturais-culturais, em especial na associação de significados simbólicos não imediatamente tangíveis à funcionalidade da natureza. Nossa pergunta deve ser: Como queremos transmitir essa herança para as gerações futuras? Como queremos nos inscrever em sua trajetória? 


\subsection{A funcionalidade: as paisagens na ecologia}

A separação natural-cultural é desastrosa. O Brasil avançou nesse aspec-

to, mas há ainda essa dicotomia muito presente no cardápio de opções legais para proteger a paisagem. Há experiências relacionadas à gestão da biodiversidade em suas interfaces com a dinâmica social. A conservação deve buscar novas formas de interpretar as interações e incorporar novas práticas dirigidas à gestão da biodiversidade nos desenhos de ANT. Nesse sentido, o tombamento de paisagens emerge como um campo privilegiado e ilimitado para geração de conhecimento e laboratório de inovação teórica e metodológica, não separando sociedade e natureza, tampouco cultura e natureza.

A descrição de aspectos relativos à fisiografia do bem protegido e o estado de conservação e proteção da paisagem, muitas vezes, não fornecem uma visão do conjunto, tampouco esclarecem o estado de fragmentação dos hábitats, característicos do mosaico paisagístico (METZGER, 2003), aspectos do desenvolvimento da cobertura vegetal, níveis de fragilidade potencial do relevo (ROSS, 1994), setores e classes de declividade onde se instalarão as atividades pretendidas pelos interessados, entre outros. Durante a atuação em mais de uma década como Conselheira do Condephaat, analisei pareceres que se fundamentavam somente nas ocorrências pontuais obtidas em diagnóstico rápido e simplificados feitos por órgãos ambientais com foco exclusivo nos estágios sucessionais da vegetação. Esse aspecto é importante, mas questionável e insuficiente para a proteção da paisagem. Não há nenhuma ponderação sobre fragmentação de área e conectividade, aspectos considerados fundamentais na proteção, particularmente da Mata Atlântica (RIBEIRO, 2009).

Vale lembrar que os tombamentos de áreas naturais, especialmente o da Serra do Mar, se basearam na preservação dos últimos grandes fragmentos em áreas contínuas e compactas de florestas tropicais úmidas (Mata Atlântica) do estado de São Paulo - como já recomendava a pesquisa científica sobre a conservação de florestas tropicais e que se tornaram consistentes com os estudos da ecologia da paisagem nas últimas décadas. O problema, portanto, é a autorização da continuidade do processo de fragmentação sem nenhuma análise da estrutura, da configuração e da composição paisagística que garantiria a preservação dos processos funcionais em bens naturais 
tombados. Não é o caso de retomar todas as fundamentações, mas sugerir, a seguir, alguns aspectos que podem avançar nas análises técnicas do uso da terra em ANT. Fragmentar a floresta tropical úmida é destruir o bem tombado com esse propósito.

A maioria dos bens naturais tombados pelo Condephaat tem em sua argumentação o valor paisagístico, a importância da paisagem como herança, a paisagem cultural como produto em que forma e conteúdo expressam singularidades históricas, culturais e ambientais. No caso da Serra do Mar, fala-se também no banco genético - expressão usada na época e que hoje corresponde ao conceito de biodiversidade. As paisagens naturais tombadas devem ser analisadas do ponto de vista da herança biogeográfica, seguindo a definição do objeto a ser protegido pelo estatuto do tombamento.

Cabe ainda considerar que as ANT representam mosaicos de coberturas vegetais em diferentes estágios de desenvolvimento, relevos marcantes e únicos, redes hídricas específicas, usos pretéritos que se associaram à dinâmica ambiental interferindo pouco nos processos biogeofísicos que atuaram na formação da paisagem. No caso da Serra do Japi, Serra do Mar, Serra da Cantareira, Pedra Grande, entre outros bens naturais tombados, há grande destaque para as formações florestais, a morfoestrutura e morfoescultura do relevo. Nesse sentido, percebe-se que o valor paisagístico está intrinsecamente associado à dinâmica dos processos biológicos de cobertura associados ao suporte que é o relevo. Ou seja, proteger um bem natural tombado é proteger processos de formação e manutenção desse sistema. Ocorre que as avaliações técnicas são extremamente reducionistas e não sustentam decisões que protegem essa complexidade.

Atualmente existem abordagens que podem auxiliar muito na tomada de decisões quanto a essa proteção. Dois grandes campos se cruzam: de um lado, a ecologia da paisagem e, de outro, os estudos da fragilidade potencial do relevo.

$\mathrm{Na}$ ecologia da paisagem, um grande e significativo volume de estudos tem apontado para o funcionamento do sistema paisagem. Esses estudos oferecem modelos espaciais que são fundamentais para a avaliação técnica das interferências e da degradação que novos objetos técnicos podem trazer à paisagem protegida. A maioria dos estudos de ecologia 
da paisagem se fundamenta na análise do desenho dos fragmentos em sua estruturação espacial (configuração) e composição. Essas análises nos auxiliam a inferir como os fluxos ocorrem no mosaico de uso da terra. Conhecer o mosaico e avaliar se a paisagem resultante é mais menos ou mais permeável aos fluxos gênicos é o fundamental para decidir sobre novos usos, a continuidade destes e sua reversão. Apesar de as análises de desenho terem bons descritores da paisagem, eles não abordam as interações (trocas) das manchas conectadas entre si. Nesse sentido, as análises de fragmentação devem ser acrescidas do estudo das interações (trocas). Um bom caminho de observação dessas interações espaciais para melhor reconhecer e analisar as mudanças de heterogeneidade da paisagem é pela identificação das fronteiras entre os diferentes usos adjacentes (METZGER, MULLER, 1996; ROLDÁN MARTÍN et al, 2003). Para alguns autores, é esse entendimento da heterogeneidade que nos auxilia na conservação de fato da diversidade biológica e na gestão de paisagens protegidas.

Portanto, o problema para conservação é buscar maior continuidade, quantidade de hábitat, forma, conectividade e evitar tendências de fragmentação e redução da quantidade de hábitats.

Uma equipe técnica que avalia usos da terra precisa ser preparada para utilizar procedimentos consistentes sobre a proteção dos bens naturais tombados. Para isso, sugerimos alguns procedimentos básicos para avaliar a fragmentação de hábitats em bens naturais tombados:

a. Avaliação de uso da terra a partir de legendas que auxiliem na identificação de permeabilidade da paisagem

Esta caracterização pode ser feita por métodos de análise espacial, mas, numa primeira aproximação, pode-se partir da interpretação visual em ortofotos ou imagens de satélite de modo analógico ou utilizando softwares adequados (Spring, ArcGis, QuantumGis, entre outros). A escala ideal para essa análise é a 1:50.000 (escala regional) e de detalhe 1:25.000 ou 1:10.000 em se tratando de fragmentos no interior do perímetro tombado ou na área envoltória. Nessa análise inicial, deve-se mapear os fragmentos e classificá-los quando ao tamanho, forma e proximidade. O mapa da área em estudo deve conter também a rede de drenagem e ser acompanhado por um mapa 
de declividades para avaliar indicativos de perigo de escorregamentos ou inundação ${ }^{12}$.

b. Análise dos padrões de fragmentação de hábitats na paisagem

Existem muitos estudos e usos de medidas de fragmentação. Para uma análise preliminar, recomenda-se uma avaliação da estrutura da paisagem a partir de um conjunto de métodos designado como medidas de estrutura (LANG, 2009; METZGER, 2003; SARTORELLO, 2014). Há dois grandes grupos de procedimentos que resultam em informações preciosas para a tomada de decisão:

- Métricas de Composição - que consideram número de manchas, tamanho e forma.

- Métricas de Configuração - que consideram o arranjo espacial, a organização ou disposição dos fragmentos no espaço.

c. Conectividade

A conectividade é a capacidade de uma paisagem facilitar fluxos entre os seus elementos. São componentes desse estudo: corredores; permeabilidade da matriz; pontos de ligação (stepping stones). A análise desses parâmetros auxilia no diagnóstico funcional de uma paisagem e ajuda a propor medidas que melhorem o desenho da preservação dos bens tombados, tais como a definição de área envoltória, manchas de vegetação que se conectam entre si e diagnosticar a porcentagem de fragmentação. Esta é uma análise que poderia ser feita, por exemplo, para avaliar autorizações de supressão de vegetação, pois não basta ter uma reserva legal dentro de uma gleba, é preciso saber se ela é funcional para a paisagem em seus fluxos, se permite conexões, se é permeável ou se favorece pontos de ligação.

Os corredores ou conectores desempenham funções importantes na manutenção de hábitats muito fragmentadas como os remanescentes de Matas Atlânticas. As funções podem ser:

- Facilitar fluxos

- Reduzir riscos de extinção local e favorecer a recolonização

12. Para este tipo de mapa, pesquisar as metodologias em uso pelo Instituto de Pesquisas Tecnológicas (IPT) ou pelo Instituto Geológico (IG-SMA-SP). 
- Suplementar hábitats

- Refúgio para fauna quando ocorrem perturbações

Alguns tipos de medidas podem ser aplicados aos estudos e pareceres técnicos ou mesmo estudos de um bem a ser tombado para antecipar o que se pode decidir ou não sobre sua proteção. Por exemplo, seria muito importante termos um pano de fundo do estado de fragmentação das ANT para não avaliar caso a caso. Pois preservar pequenos fragmentos caso a caso, efetivamente, não preserva nada.

d. Análise temporal dos usos da terra e suas tendências atuais

Outra avaliação de pano de fundo que deve ser feita nos estudos para decisão de usos em ANT e sua área envoltória é procurar verificar séries temporais de usos da terra para perceber a dinâmica da paisagem (tendência de maior fragmentação ou recuperação natural). Nesse caso, as bases são imagens que podem ser fotografias aéreas e imagens de satélite. Existem metodologias robustas para esse tipo de análise temporal (SARTORELLO, 2014).

e. Identificação das tipologias de manchas por fronteiras

Cartografia das zonas de contato entre as manchas ou fragmentos vizinhos utilizando o critério de buffer interno e externo ao fragmento (comando buffer Wizard do Arcgis $\left.{ }^{13}\right)$. Depois de rasterizados em células de $0,5 \mathrm{~m}^{2}$ (comando Feature to Raster), cada tipo de uso pode ser classificado em números primos de 3 a 29 (comando Reclassify). Após esse procedimento, pode-se reclassificar por sobreposição (comando Raster Calculator), e os produtos desse cálculo permitem a identificação dos tipos de vizinhança já que o resultado da multiplicação de números primos sempre resulta em combinações exclusivas. Em seguida, retornam-se as informações ao modo vetorial (comando Raster to Feature), que permite a quantificação em área e a continuidade das análises de identificação dos mosaicos. Essa identificação é feita pela frequência dos tipos de fronteira.

13. Existem softwares livres, como o QuantumGis ou QGIS, que permitem análises semelhantes. 
f. Mapa de declividades

Para completar o conjunto de informações necessárias, deve-se considerar as classes de declividade consagradamente suscetíveis a potencializar os fenômenos de movimentos rotacionais e de massa na Serra do Mar ou outros relevos dissecados. Existem métodos automáticos para produzir esse documento nos softwares já citados. Recomenda-se a escala 1:10:0oo, pois a escala 1:50:00o não é a adequada para a visualização de processos de vertentes. A seguir, apresentamos um gabarito para análise. As declividades são consagradas nos estudos de perigo e vulnerabilidade a movimentos de massa (Quadro 3).

\begin{tabular}{|c|c|}
\hline \multicolumn{2}{|c|}{ Quadro $3-$ Intervalos de declividade, grau e classes de vulnerabilidade. } \\
\hline DECLIVIDADE (\%) & CLASSE DE VULNERABILIDADE \\
\hline$>30$ & Muito Alta \\
\hline $20-30$ & Alta \\
\hline $12-20$ & Média \\
\hline $5-12$ & Baixa \\
\hline $0-5$ & Muito Baixa \\
\hline
\end{tabular}

Fonte: Adaptado de: (ROSS, 1994)

g. Áreas de Preservação Permanente (APP)

Neste item, o pano de fundo são mapas que indiquem os dispositivos previstos na Lei n. 12.651/12, particularmente para as APP hídricas, de topo de morros e outras previstas na lei. Este é um trabalho de base. Sempre é importante informar onde se situam cartograficamente as APP em escala 1:10:00o.

\section{O PRESENTE E O PASSADO}

O patrimônio é um legado que recebemos do passado, que vivemos no presente e que transmitimos às gerações futuras; uma fonte insubstituível de vida e inspiração, nosso ponto de referência, nossa identidade ${ }^{14}$ (UNESCO, 2005). 
As ANT são remanescentes da intensa intervenção humana no estado de São Paulo que alterou formas do relevo e suprimiu a vegetação nativa ao longo de séculos. O tombamento de paisagens contribuiu de fato para um bom estado de conservação das ANT nos dias atuais. O tombamento somou os níveis de proteção já existentes, como de áreas protegidas que já existiam, dando-lhes um desenho de área contínua conectada e também inaugurou a proteção da geodiversidade (por exemplo, cratera de colônia, rocha moutonnée), pois projetando-se como um buffer a mais na proteção de paisagens. As demandas de estudos de tombamento de ANT sempre superaram a capacidade de órgão em dar respostas. O patrimônio natural nunca gozou de investimentos para que pudesse desenvolver bases conceituais novas e metodologias de desenho, acompanhando a evolução do conhecimento científico e das novas possibilidades técnicas a partir das geotecnologias. De modo geral, as instituições de patrimônio praticamente assistiram ao desenvolvimento de uma série de legislações ambientais que protegem atributos, mas a paisagem como espaço total ficou relegada. A paisagem protegida pelo patrimônio não tem o mesmo prestigio das Unidades de Conservação, que também carecem de muito investimento, mas estão mais bem estruturadas na gestão e governança.

O tombamento de áreas naturais se baseou na perspectiva de preservação de áreas extensas cujo arranjo espacial complexo requer uma revisão dos conceitos de paisagem. O conceito de paisagem de exceção, com monumentais formas excepcionais associadas a uma visão de ampla continuidade ecossistêmica, já vinha sendo evidenciado nas pesquisas científicas como importante fundamento para o planejamento da conservação. Havia uma confluência de conceitos que demonstravam o fato de que a natureza para ser conservada dependia fundamentalmente da visão sistêmica de processos geoecológicos e socioespaciais e que áreas maiores (mais extensas) eram mais favoráveis à conservação do dinamismo da fauna e flora. A paisagem geográfica vista como síntese de processos estava sendo alçada a fundamento para desenho patrimonial, e a ideia de conjunto cênico foi, naquele momento, uma visão acertada da dinâmica de proteção de processos funcionais.

Desde a década de 1960, a pesquisa científica sobre desenho da conservação já recomendava proteção de áreas contínuas e conectadas. O que pouco se assinala é que o tombamento de paisagens, na busca de ordenar 
e orientar o planejamento territorial, abriu-se uma possibilidade infinita de ideias criativas para o modelo espacial de ocupação e uso da terra, nem sempre vistos dessa maneira pelos interessados em projetos cuja forma de ocupação compromete os atributos naturais e, em decorrência, a paisagem que os articula é constantemente "apagada" ou desorganizada por sua degradação.

Mesmo com o esforço de regulamentar as resoluções de tombamento mediante detalhamentos técnicos, parcerias institucionais e aprimoramento da concepção de desenho patrimonial de paisagens protegidas, o Condephaat nunca investiu adequadamente nas suas próprias equipes de especialistas que poderiam avançar nos modelos de ANT. Um instrumento de proteção precisa ser desenvolvido pela capacidade técnica. Isso nunca ocorreu adequadamente no Condephaat. Pelo contrário, mesmo em períodos em que desfrutou de capacidade técnica diferenciada dos seus técnicos, sempre se questionou sobre a importância das ANT. O Condephaat é o único órgão do governo que tem em suas prerrogativas a proteção da paisagem. Objeto complexo que parte de uma visão do espaço total integrado. Passados 50 anos de experiência de estudos de paisagens protegidas, temos visto como ainda é difícil a gestão das grandes extensões territoriais tombadas que articulam diferentes sistemas de paisagem e sujeitos sociais que buscam linguagens científicas, técnicas comuns e afinadas. De um lado, a falta de estrutura do Condephaat que não se preparou para corresponder ao desafio proposto. De outro, ainda há pouca visibilidade da importância da gestão da paisagem no planejamento territorial

Mas a paisagem natural é cultural. Não é vazia de valores e significados. Portanto, proteger os hábitats reconhecidamente importantes depende de orientar os usos, iluminar as formas de usos adotadas e manter fluxos biológicos na paisagem. Acredito que é possível ordenar atividades a partir de uma visão mais completa da paisagem protegida. Devemos sair dos argumentos genéricos e perigosos para o futuro dos recursos.

Sobre o aspecto educador, as legislações ambientais vêm incluindo em seu processo de construção elementos participativos. $\mathrm{O}$ tombamento é uma medida que constrange usos, mas permite consensos e pretende iluminar os usos que mais se adequam à proteção do patrimônio. É um trabalho de embates o tempo todo e de tensões políticas. É um trabalho técnico científico e educador. 


\section{REFERÊNCIAS}

AB'SABER, Aziz Nacib. Diretrizes para uma política de preservação de reservas naturais do Estado de São Paulo. Boletim de Geografia e Planejamento. São Paulo: Instituto de Geografia da USP, n. 30, p. 7-19, 1977.

AB'SABER, Aziz Nacib. Bases conceituais e papel do conhecimento na previsão de impactos. In: MÜLLER-PLANTENBERG, C. AB'SABER, A.N. (Orgs.). Previsão de impactos: o estudo de impacto ambiental no Leste, Oeste e Sul. Experiências no Brasil, na Rússia e na Alemanha. 2. ed. São Paulo: Edusp, 2002.

DETONI, Sandro Francisco. Natureza e patrimônio cultural: a geomorfologia como referencial metodológico no tombamento de áreas naturais. Tese (Doutorado em Geografia Física) Faculdade de Filosofia, Letras e Ciências Humanas, Universidade de São Paulo. São Paulo, 2016. DOI 10.11606/T.8.2016.tde-09082016-121625. Disponível em: http://www.teses.usp.br/teses/ disponiveis/8/8135/tde-09082016-121625/pt-br.php. Acesso em: 12 nov. 2018.

LANG, Stephan; BLASCHKE, Thomas. Análise da paisagem com SIG. Trad. Herman Kux. São Paulo: Oficina de Textos, 2009.

MENESES, Ulpiano B. A paisagem como fato cultural. In: YAZIGI, Eduardo et al (Org). Turismo e paisagem. São Paulo: Contexto, 2002. p. 29-64.

METZGER, Jean Paul. Restauração ecológica de ecossistemas naturais. In: KAGEYAMA, Paulo et al. Restauração ecológica de ecossistemas naturais. Botucatu: Fundação de Estudos e Pesquisas Agrícolas e Florestais, 2003. v. 1. p. 49-76.

METZGER, Jean P.; MULLER, Etienne. Characterizing the complexity of landscape boundaries by remote sensing. Landscape Ecology. 1996, v. 11, 65-77.

RIBEIRO, Milton Cezar et al. The Brasilian Atlantic Forest: how much is left, and how is the remaining forest distributed? Implications for conservation. Biological Conservation, v.142, n.6, p.1141-1153, 2009.

ROLDÁN MARTÍN, M. J. et al. Landscape mosaics recognition and changes over time: a methological approach. In: MANDER, U. ed. Multifuncional landscape: continuity and change. Southampton: WIT Press, 2003. v. 3.

ROSS, Jurandyr L. S. Análise empírica dos ambientes naturais e antropizados. Revista do Departamento de Geografia da USP, São Paulo, n. 8, 1994.

SARTORELLO, Ricardo. Interações em estudos para conservação: conceitos e técnicas para análises geográficas e ecológicas da paisagem. 2014. Tese (Doutorado em Geografia Física) Faculdade de Filosofia, Letras e Ciências Humanas, Universidade de São Paulo. São Paulo. DOI 10.11606/T.8.2014.tde-24032015-122734. Disponível em: http://www.teses.usp.br/teses/disponiveis/8/8135/tde-24032015-122734/pt-br.php. Acesso em: 12 nov. 2018.

SCIFONI, Simone. A construção do patrimônio natural. 2006. Tese (Doutorado em Geografia Humana) - Faculdade de Filosofia, Letras e Ciências Humanas, Universidade de São Paulo. São Paulo, 2006. DOI 10.11606/T.8.2006.tde-27122006-104748. Disponível em: http://www.teses.usp. br/teses/disponiveis/8/8136/tde-27122006-104748/pt-br.php. Acesso em: 12 nov. 2018.

SCIFONI, Simone. Os diferentes significados do patrimônio natural. Revista Diálogos, v. 10, n. 3, p. 55-78, 2006. 
UNESCO. Carpeta de información sobre el patrimonio mundial . Paris, 2005.

VIOLA, Eduardo. A globalização da política ambiental no Brasil (1990-1998). In:

INTERNATIONAL CONGRESS OF THE LATIN AMERICAN STUDIES ASSOCIATION, 21,

Chicago, 24-26 set. 1998. Disponível em: http://lasa.international.pitt.edu/LASA98/Viola.pdf.

Acesso em: 12 nov. 2018.

VIOLA, Eduardo. Meio ambiente, desenvolvimento e cidadania. São Paulo: Cortez, 1995. 